\title{
ANALISIS PERSEPSI VIRTUAL BRAND COMMUNITY TERHADAP KINERJA EKUITAS MEREK DISPOSABLE DIAPER MEREK SWEETY (SURVEI PADA ANGGOTA FAN PAGE FACEBOOK BUNDA CERMAT)
}

\author{
Leni Deniarni \\ Universitas Pendidikan Indonesia \\ lenideniarti@ student.upi.edu \\ Lisnawati \\ Universitas Pendidikan Indonesia \\ lisnawati@upi.edu
}

\begin{abstract}
ABSTRAK
Persaingan yang kompetitif dalam industri fast moving consumer good (FMCG) ditandai dengan turun naiknya ekuitas merek suatu produk, khususnya pada lini disposable diaper yang berasal dari perusahaan PT. Softex Indonesia dengan merek Sweety. Untuk dapat bertahan di tengah persaingan, perusahaan dituntut untuk menciptakan strategi yang dapat memperkuat ekuitas merek karena hanya produk yang memiliki ekuitas merek yang kuat yang mampu bersaing untuk merebut dan menguasai pasar. Salah satu strategi yang dapat dilakukan adalah dengan strategi virtual brand community. Penelitian ini bertujuan untuk 1) memperoleh temuan mengenai virtual brand community diaper Sweety, 2) memperoleh temuan mengenai ekuitas merek diaper Sweety dan 3) memperoleh temuan mengenai seberapa besar virtual brand community dapat mempengaruhi ekuitas merek diaper Sweety. Dimensi virtual brand community antara lain consciousness of kind, ritual and tradition dan sense of moral responsibility. Sedangkan dimensi ekuitas merek adalah brand saliance, brand performance, brand imagery, brand judgment, brand feeling dan brand resonance.

Objek penelitian ini adalah anggota komunitas Sweety di fan page Facebook Bunda Cermat. Variabel bebas (X) dalam penelitian ini adalah virtual brand community dan ekuitas merek (Y) sebagai variabel tidak bebas. Jenis penelitian yang digunakan adalah deskriptif, verifikatif, dan metode yang digunakan adalah explanatory survey dengan teknik simple random sampling, dengan jumlah sampel 100 responden di fan page Facebook Bunda Cermat. Teknik analisa data yang digunakan adalah analisis regresi linier sederhana dengan alat bantu software komputer SPSS 21.0.

Hasil yang diperoleh dalam penelitian menyatakan bahwa virtual brand community berpengaruh terhadap ekuitas merek pada diaper Sweety sebesar 81,3\%. Dari hasil penelitian terhadap pengujian hipotesis dapat diketahui bahwa virtual brand community memiliki pengaruh yang positif terhadap ekuitas merek. Berdasarkan hasil penelitian melalui analisis regresi linier sederhana terdapat pengaruh dari virtual brand community terhadap ekuitas merek diaper Sweety. Penulis merekomendasikan agar perusahaan lebih selektif dalam memilih media komunikasi virtual brand community sebagai salah satu strategi untuk meningkatkan ekuitas merek diaper Sweety.
\end{abstract}

Kata kunci: ekuitas merek, virtual brand community PENDAHULUAN

Pengembangan industri pengolahan perlu terus ditingkatkan ekspansinya pada berbagai sektor sehingga dapat menjadi alternatif pilihan strategi untuk menjamin pertumbuhan ekonomi Indonesia di tahun 2014. Hal ini sangat strategis

seiring dengan meningkatnya konsumsi masyarakat, maka kebutuhan akan barang-barang hasil industri juga meningkat. Peningkatan tersebut diikuti dengan peningkatan dari pendapatan per kapita Indonesia, dilihat dari semakin meningkatnya nilai pendapatan perkapita 
dari tahun ke tahun yakni pada tahun 2009-2013. Peningkatan pendapatan perkapita setiap tahunnya dapat dilihat dari Gambar 1 di bawah ini:

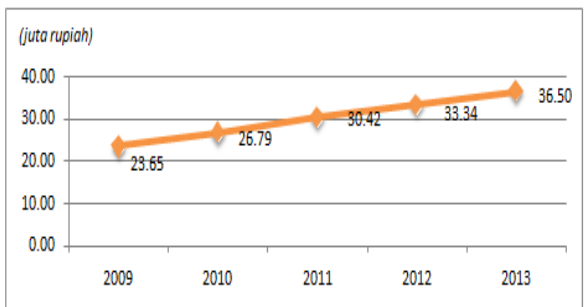

Sumber: http:// www.bps.go.id akses 13 Februari 2014 pukul 20:58

\section{GAMBAR 1 \\ PENDAPATAN PER KAPITA INDONESIA} TAHUN 2009-2013

Berdasarkan data diatas bahwa pendapatan perkapita Indonesia meningkat dari tahun ke tahunnya seperti terjadi pada tahun 2013 peningkatan sebesar 2,16\% dari 33,34 juta rupiah pada tahun 2012 menjadi 36,50 juta rupiah pada tahun 2013. Hal ini membuat daya beli masyarakat akan kebutuhan konsumsinya pun meningkat.

Selain ditandai dengan peningkatan pendapatan perkapita faktor lain yang ikut mempengaruhi adalah pertumbuhan kelas menengah yang mencapai 131 juta orang dan menyebabkan peningkatan kesejahteraan masyarakat yang dapat memicu naiknya permintaan maupun konsumsi produk-produk fast moving consumer goods (FMCG).

Pertumbuhan ekonomi ini juga mendorong peningkatan kesejahteraan masyarakat kelas menengah yang berdampak pada meningkatnya permintaan terhadap pendidikan, kesejahteraan dan pembangunan. Peningkatan permintaan bukan saja berimbas terhadap produk consumer goods, tapi juga berpotensi mendorong tumbuhnya produk dengan positioning yang mengarah pada kesehatan. Hal lain yang terjadi adalah perubahan perilaku konsumen dan semakin terhubung secara digital.

Sejalan dengan kondisi tersebut, dapat dipastikan akan banyak pemain baik yang sudah ada maupun baru masuk ke Indonesia, yang melihat potensi besar untuk menumbuhkan bisnis di Indonesia. Tak ayal, persaingan di industri FMCG pun tak bisa dihindari. Persaingan pun bukan hanya terjadi antarperusahaan, tapi juga antarnegara.

Meskipun demikian, pasar industri consumer goods di Indonesia kian tumbuh positif dengan peningkatan sebesar 9,6\% di tahun 2011 dari tahun sebelumnya, nilai pasar industri ini telah mencapai RP 165,95 triliun. Pada tahun 2010, nilai penjualan consumer goods naik $11 \%$ dibanding tahun sebelumnya. Pertumbuhan yang terus menerus positif tentunya akan menaikkan nilai investasi pada bidang ini. Seperti tertera pada Gambar 2 dibawah ini mengenai pasar industri consumer goods di Indonesia dari tahun 2009. 2013.

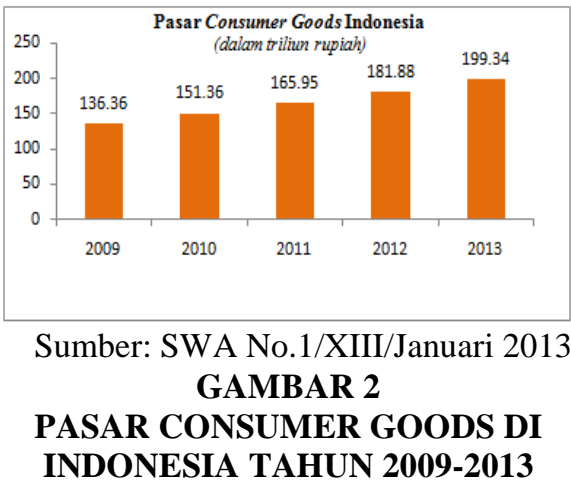

Berdasarkan data diatas pasar industri consumer goods di Indonesia semakin meningkat mulai dari tahun 2009 sebesar 136,36 triliun rupiah terus mengalami peningkatan hingga mencapai nilai sebesar 199,34 triliun rupiah pada tahun 2013 dimana kenaikan sebesar 17,46 triliun rupiah dari tahun sebelumnya yaitu sebesar 181,88 triliun rupiah.

Pertumbuhan pasar dalam industri ini sangat erat kaitannya dengan peningkatan penjualan di beberapa perusahaan, baik perusahaan multinasional maupun lokal. Tiap-tiap pemain dalam industri biasanya memiliki spesifikasi produk khusus yang menjadi andalan mereka.

Setiap pemain di industri ini memiliki kategori produk yang beragam dan pangsa pasar yang berbeda-beda. Beberapa diantaranya melibatkan banyak pemain yang mengakibatkan persaingan yang kompetitif dalam industrinya. Salah satunya, persaingan pasar yang sangat sengit terjadi pada pasar produk popok bayi sekali pakai (disposable diaper).

Masyarakat Indonesia yang memiliki kecenderungan konsumtif dan serba praktis, membuat produk popok bayi sekali pakai (disposable diaper) memiliki pangsa pasar yang besar dan jumlah konsumen (permintaan) yang tinggi. Kondisi ini menyebabkan persaingan yang kompetitif di industri disposable diaper. Data yang dilansir perusahaan riset pasar AC Nielsen Indonesia yang menunjukkan bahwa nilai pasar popok bayi sekali pakai (disposable diaper) mencapai Rp. 3,10 triliun pada tahun 2010 dan meningkat ke Rp. 3,79 triliun pada tahun 2011, lalu melonjak ke angka Rp. 4,87 triliun pada tahun 
2012 (Sumber: Majalah SWA No.5/XXIX/7-17 Maret 2013).

Terus meningkatnya pasar disposable diaper tidak lepas dari jumlah populasi bayi yang demikian besar nya. Berdasarkan data dari Badan Pusat Statistik angka kelahiran bayi yang cukup tinggi dan semakin meningkat dari tahun ke tahunnya pun membuat pasar bayi semakin menjadi salah satu lahan bagi para produsen disposable diaper untuk bersaing di pasar ini.

\section{GAMBAR 3}

\section{ANGKA KELAHIRAN BAYI DI INDONESIA} TAHUN 2007-

\section{3}

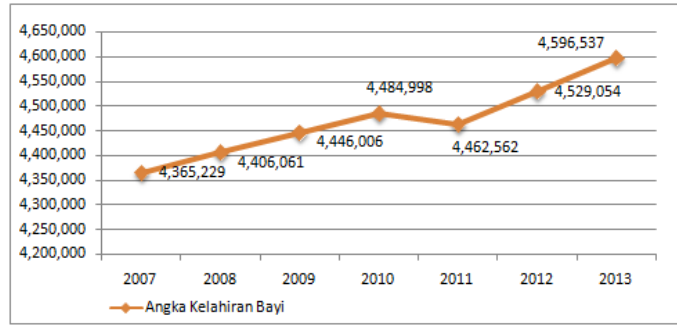

Sumber: Pusdatin Kemenkes RI (Pusat Data dan Informasi Kementerian Kesehatan)

Berdasarkan Gambar 1.3 diatas tercacat dari tahun 2007 bahwa jumlah bayi yang lahir adalah sebanyak 4.365.229 jiwa pertahun, tahun 2008 sebanyak 4.406.061 jiwa, tahun 2009 sebanyak 4.446.006 jiwa, tahun 2010 sebanyak 4.484.998 jiwa, tahun 2011 jumlah nya menurun dari tahun sebelumnya yaitu sebanyak 4.462 .562 jiwa, tahun 2012 sebanyak 4.529.054 jiwa dan pada tahun 2013 mencapai jumlah angka kelahiran yaitu sebanyak 4.529.054 jiwa.

Tingginya angka kelahiran bayi di Indonesia memberikan peluang pasar yang cukup diminati para produsen untuk bersaing di pasar disposable diaper. Namun, menurut Handyanto Widjojo, pakar pemasaran Prasetiya Mulya berpendapat bahwa faktor pendorong utama adalah tumbuhnya kelas menengah-atas dan bergesernya perilaku konsumen, khususnya keluarga dengan anak bayi dan balita di Indonesia. Daya beli pada segmen ini meningkat dan mereka semakin mempertimbangkan sisi kepraktisan, termasuk dalam pemilihan dan penggunaan popok bayi dari yang tradisional (dapat dicuci) menjadi yang sekali pakai (disposable). Merek-merek popok bayi pun bermunculan baik yang telah ada sejak lama maupun para pemain baru.
TABEL 1
PERUSAHAAN-PERUSAHAAN
DISPOSABLE DIAPER DI INDONESIA

\begin{tabular}{|l|l|l|}
\hline No. & \multicolumn{1}{|c|}{ Perusahaan } & \multicolumn{1}{c|}{ Produk } \\
\hline 1. & P\& G & Pampers \\
\hline 2. & UniCham & Mamipoko \\
\hline 3. & PT. Softex Indonesia & Sweety dan Happy Nappy \\
\hline 4. & Kimberly Clark Indonesia & Huggies \\
\hline
\end{tabular}

Sumber: Modifikasi Berbagai sumber

Tabel 1 diatas menunjukan beberapa perusahaan yang memproduksi disposable diaper yakni Softex Indonesia dengan Sweety dan Happy Nappy, UniCharm dengan Mamipoko, dan P \& G dengan Pampers dan Kimberly Clark Indonesia dengan Huggies.

Adapun pangsa pasar disposable diaper pada tahun 2011-2013 dapat dilihat pada Tabel 2 dibawah ini.

\section{TABEL 2}

\section{PANGSA PASAR DISPOSABLE DIAPER DI} INDONESIA TAHUN 2011-2013

\begin{tabular}{|c|c|c|c|c|}
\hline \multirow{2}{*}{} & \multirow{2}{*}{ Merek } & \multicolumn{3}{|c|}{ Pangsa Pasar (\%) } \\
\cline { 3 - 5 } & & $\mathbf{2 0 1 1}$ & $\mathbf{2 0 1 2}$ & $\mathbf{2 0 1 3}$ \\
\hline 1. & Mamypoko & 26 & 62 & 58,4 \\
\hline 2. & Pampers & 15,3 & 10,4 & 19,3 \\
\hline 3. & Sweety & 27 & 17,6 & 15,9 \\
\hline 4. & Huggies & - & 0,9 & 0,6 \\
\hline
\end{tabular}

Sumber: SWA No.5/XXIX/7-17 Maret 2013,

SWA No.4/XIII/April 2012,

http://masnov.com/analisis-perang-popok-bayi-

sekali-pakai/

akses 6 September 2014 pukul 20:22

Salah satu yang menjadi parameter ukuran keberhasilan suatu merek dalam kompetisi adalah market share, berdasarkan Tabel 2 diatas bahwa pangsa pasar pada merek MamyPoko kokoh di puncak dengan menguasai pangsa pasar sebesar $62 \%$ pada tahun $2012,58,4 \%$ pada tahun 2013 meskipun pada tahun 2011 hanya mendapat pangsa pasar sebesar 26\% kalah tipis dengan Sweety yang pada tahun 2011 mendapat pangsa pasar sebesar $27 \%$ namun nilai pasar nya dari tahun ketahun merek Sweety belum mampu menduduki posisi tertatas. Pada tahun 2012 Sweety mendapat persentase sebesar $17,6 \%$ dan pada tahun 2013 sebesar 15,9\%. Hal ini mengindikasikan bahwa merek Sweety kurung diminati kaum ibu sebagai pilihan popok bayi nomor satu di Indonesia.

Parameter untuk bisa melihat tingkatan merek dapat dilihat melelui Top Brand Index (TBI) yaitu penghargaan tertinggi di bidang merek, yang hanya diberikan kepada merek-merek yang berhasil meraih posisi puncak dalam tiga kategori, yaitu mind share atau posisi merek di dalam benak konsumen, market share atau posisi merek berdasarkan pemakaian oleh konsumen dan commitment share, yaitu posisi merek 
berdasarkan pada keinginan konsumen untuk menggunakannya lagi di masa mendatang (Sumber: http://www.top-brand.com akses 1 Februari 2014 pukul 13:55). Untuk lebih jelas mengenai Top Brand Index disposable diaper dapat dilihat pada Tabel 3 di bawah ini.

TABEL 3

TOP BRAND INDEX FOR KIDS (TBI) DISPOSABLE DIAPER

TAHUN 2012-2014

PANEL IBU

\begin{tabular}{|c|c|c|c|c|c|c|c|}
\hline \multirow{2}{*}{ No } & \multirow{2}{*}{ Merek } & \multicolumn{3}{|c|}{ Top Brand Index (\%) } & \multicolumn{4}{|c|}{ Peringkat } \\
\cline { 3 - 8 } & & 2012 & 2013 & 2014 & 2012 & 2013 & 2014 \\
\hline 1. & Mamypoko & 52,7 & 61,8 & 54,3 & 1 & 1 & 1 \\
\hline 2. & Pampers & 18,4 & 19,2 & 22,3 & 2 & 2 & 2 \\
\hline 3. & Sweety & 17,4 & 12,3 & 11,5 & 3 & 3 & 3 \\
\hline 4. & Huggies & 3,8 & - & 4,1 & 4 & - & 4 \\
\hline
\end{tabular}

Sumber: http://www.top-brand.com akses 5 Juni 2014 pukul 15:55

Berdasarkan Tabel 3 Top Brand Index disposable diaper terjadi kenaikan persentase pada merek Pampers dan Huggies dari tahun ketahun dengan persentase masing-masing sebesar $18,4 \%$ dan $3,8 \%$ pada tahun 2012 menjadi $22,3 \%$ dan 4,1\% pada tahun 2014 sedangkan untuk merek Mamypoko dan Sweety, mengalami penurunan persentase. Walupun penurunan persentase terjadi pada Mamypoko tetapi dilihat dari jumlah persentasenya Mamypoko tetap berada pada peringkat pertama untuk kategori disposable diaper yaitu sebesar $52,7 \%$ pada tahun 2012, 61,8\% pada tahun 2013 dan $54,3 \%$ pada tahun 2014 dan posisi peringkat pertamanya tidak pernah digantikan oleh merek lain dari tahun ketahun. Sedangkan untuk merek Sweety penurunan persentase terus terjadi selama tiga tahun beturut-turut yaitu sebesar $17,4 \%$ pada tahun 2012, 12,3\% pada tahun 2013 dan 11,5\% pada tahun 2014. Dari segi peringkatpun merek Sweety berada pada posisi ke-3, dibawah merek Pampers dan MamyPoko. Hal ini mengindikasikan bahwa kurangnya minat penggunaan merek Sweety dibandingkan dengan merek disposable diaper yang lainnya, sehingga membuat merek Sweety melemah atau dapat dikatakan ekuitas merek Sweety rendah dan menurun.

Sweety belum bisa melakukan peningkatan apapun seperti halnya dalam market share ataupun top brand, Sweety perlu melakukan strategi agar produknya tidak hilang begitu saja yang terus mengalami penurunan. Tabel di bawah ini menunjukan pangsa merek di industri disposable diaper untuk mengetahui sejauh mana merekmerek tersebut menguasai pasar.
TABEL 4

BRAND SHARE DISPOSABLE DIAPER TAHUN 2012-2014

\begin{tabular}{c|c|c|c|c|c|c|c|}
\hline \multirow{2}{*}{ No } & \multirow{2}{*}{ Merek } & \multicolumn{3}{|c|}{ Brand Share (\%) } & \multicolumn{3}{|c|}{ Peringkat } \\
\cline { 3 - 8 } & & $\mathbf{2 0 1 2}$ & $\mathbf{2 0 1 3}$ & $\mathbf{2 0 1 4}$ & $\mathbf{2 0 1 2}$ & $\mathbf{2 0 1 3}$ & $\mathbf{2 0 1 4}$ \\
\hline 1. & Mamypok0 & 31,0 & 33,90 & 36,16 & 1 & 2 & 2 \\
\hline 2. & Pampers & 27,4 & 38,70 & 35,46 & 3 & 1 & 3 \\
\hline 3. & Sweety & 28,6 & 33,54 & - & 2 & 3 & - \\
\hline 4. & Huggies & - & - & 39,12 & - & - & 1 \\
\hline
\end{tabular}

Sumber: SWA No.11/XXVII/24 Mei-6 Juni 2012, SWA No.18/XXIX/29 Agustus-11 September 2013, SWA No.12/XXX/5-18 Juni 2014

Berdasarkan Tabel 4 diatas bahwa penyebaran persentase dari merek popok bayi cukup merata berkisar antara 20-40\%. Peringkat pertama pun dari tahun ke tahun berganti merek yang memiliki peringkat pertama. Namun pada merek Sweety tidak pernah berada pada peringkat pertama penurunan pun terjadi di tahun 2013 sebesar 4,94\% dan pada tahun 2014 tidak memiliki peringkat. Maka dari itu dapat diindikasikan bahwa penguatan merek Sweety secara perlahan terus menurun.

Ekuitas merek dapat diukur dengan tingkat pengenalan konsumen terhadap produk, persepsi konsumen terhadap kualitas produk dan keseluruhan nilai yang dimiliki suatu merek. Berikut Tabel 5 menunjukkan hasil Pra penelitian yang dilakukan secara online kepada komunitas Facebook Bunda Cermat dengan responden sebanyak 45 responden.

\section{TABEL 5}

INDEKS NILAI MEREK DISPOSABLE DIAPER PADA KOMUNITAS FACEBOOK BUNDA CERMAT

\begin{tabular}{|c|c|c|c|c|}
\hline Nama Merek & $\begin{array}{c}\text { Merek popok } \\
\text { yang diingat } \\
\text { konsumen }\end{array}$ & $\begin{array}{c}\text { Iklan popok } \\
\text { yang diingat } \\
\text { konsumen }\end{array}$ & $\begin{array}{c}\text { Kualitas popok } \\
\text { yang baik } \\
\text { dibenak } \\
\text { konsumen }\end{array}$ & $\begin{array}{c}\text { Merek popok } \\
\text { yang } \\
\text { digunakan }\end{array}$ \\
\hline Mamypoko & 9 & 27 & 12 & 19 \\
\hline Pampers & 29 & 12 & 23 & 6 \\
\hline Sweety & 7 & 4 & 6 & 13 \\
\hline Dll & 0 & 2 & 4 & 7 \\
\hline Jumlah & 45 & 45 & 45 & 45 \\
\hline
\end{tabular}

Sumber: Pra Penelitian September 2014

Hasil pra penelitian pada Tabel 5 menunjukkan bahwa responden memilih satu merek popok dalam satu kategori tetapi dalam kategori lain belum tentu responden memilih merek yang sama. Pada kategori merek popok yang diingat konsumen, banyak responden memilih merek Pampers dan kedua Mamypoko. Dalam kategori yang lain pun kedua merek Pampers dan Mamypoko bersaing menduduki peringkat teratas, sedangkan merek Sweety masih jauh lebih kecil nilainya dibandingkan kedua 
merek popok Pampers dan Mamypoko. Hal tersebut menunjukkan bahwa merek Sweety belum mampu menunjukkan kesan baik dibenak konsumen dan dapat dikatakan ekuitas merek Sweety rendah.

Situasi persaingan yang tinggi dalam produksi disposable diaper mengakibatkan usaha perusahaan untuk masuk kepada pikiran konsumen menjadi sangat penting dengan cara komunikasi pemasaran kepada konsumen untuk membentuk sebuah merek yang kuat.

Kotler dan Amstrong (2012:5) "Marketing as the process by which companies create value for customers and build strong customers relationships in order to capture value from customers in return". Artinya, pemasaran sebagai proses dimana perusahaan menciptakan nilai bagi pelanggan dan membangun hubungan yang kuat dengan pelanggan untuk menangkap nilai dari pelanggan sebagai imbalan.

Berikut adalah strategi yang dilakukan Sweety dapat dilihat pada Tabel 6 di bawah ini.

\section{STRATEGI YANG DILAKUKAN OLEH SWEETY}

\begin{tabular}{|c|c|}
\hline Strategi & Sweety \\
\hline Segmenting & $\begin{array}{l}\text { Popok sekali pakai yang dirancang untuk } \\
\text { bayi dan balita }\end{array}$ \\
\hline Targeting & Kalangan ibu kelas A, B dan C \\
\hline Product & $\begin{array}{l}\text { 1. Sweety Safe and Soft } \\
\text { Sweety baby diaper tipe perekat ini } \\
\text { memiliki lapisan "Stripy Dry Layer" } \\
\text { bertekstur lembut bergaris } \\
\text { memaksimalkan distribusi urin } \\
\text { dipopok dan cepat menarik } \\
\text { kelembapan sehingga kulit bayi tetap } \\
\text { kering sepanjang hari. } \\
\text { 2. Sweety Clothlike } \\
\text { Popok tipe perekat selembut kain } \\
\text { dengan daya serap maksimal untuk } \\
\text { pemakaian lebih lama. Perlindungan } \\
\text { "Double Leak Guards System" } \\
\text { dirancang untuk perlindungan ganda } \\
\text { mengurangi resiko bocor samping. } \\
\text { Sweety Fit Pantz } \\
\text { Popok celana mengandung Natural } \\
\text { Aloe Vera Moisturaizer yaitu lapisan } \\
\text { atas dilengkapi ekstrak alami Aloe } \\
\text { Vera untuk melindungi kulit bayi dan } \\
\text { iritasi dan kekeringan. }\end{array}$ \\
\hline $\begin{array}{l}\text { Activation/ } \\
\text { Event }\end{array}$ & $\begin{array}{l}\text { 1. Kontes Share dan Kuis Video Sweety } \\
\text { Safe and Soft (19 Februari - 16April } \\
\text { 2013) } \\
\text { 2. Hadiah Hiburan Kuis TVC Sweety } \\
\text { Safe \& Soft (18 Februari - 14April } \\
\text { 2013) } \\
\text { 3. Kejutan Poin Sweety di Alfamart / } \\
\text { Alfamidi dan Hypermart (April - } \\
\text { Agustus 2013) }\end{array}$ \\
\hline
\end{tabular}

\begin{tabular}{|c|c|}
\hline Strategi & Sweety \\
\hline & \begin{tabular}{|l} 
4. Sweety Harapan Bunda (1 Sep - 30Nov \\
2013) \\
5. How Well Do You Know About \\
Sweety Fitpantz Hello Kitty Dear \\
Daniel (26 Mar - 1Apr 2014) \\
6. Sweety Baby The Explorer (22 Mar \\
2013 - 22 Mar 2014) \\
7iburan Keluarga Kompak Sweety \\
(April-Oktober 2014) \\
8. Aksi Bocah Cilik (Oktober 2014)
\end{tabular} \\
\hline $\begin{array}{l}\text { Marketing } \\
\text { Communic } \\
\text { ations }\end{array}$ & 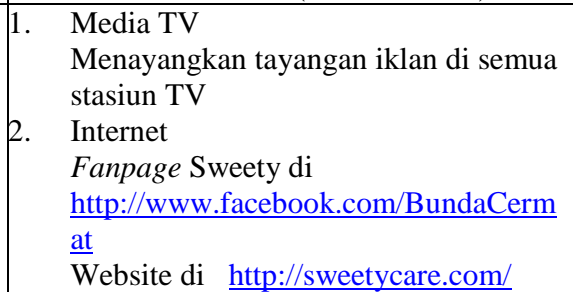 \\
\hline $\begin{array}{l}\text { Virtual } \\
\text { Brand } \\
\text { Community }\end{array}$ & $\begin{array}{l}\text { Sarana dalam mengkomunikasikan } \\
\text { kampanye kegiatan (event) dan produk } \\
\text { nya, Sweety memanfaatkan situs jejaring } \\
\text { sosial Facebook yang berdampak pada } \\
\text { pembentukan suatu komunitas yang } \\
\text { mampu menjadi wadah untuk pelanggan } \\
\text { dengan fanpage Facebook Bunda Cermat. } \\
\text { Pelanggan dapat berbagi cerita atau } \\
\text { pendapat mengenai produk dan event yang } \\
\text { diselenggarakan Sweety dalam bentuk } \\
\text { postingan dan antar sesama anggota dapat } \\
\text { memberi tanggapan berupa komentar } \\
\text { ataupun like pada status yang telah } \\
\text { diposting pada Facebook Bunda Cermat. }\end{array}$ \\
\hline
\end{tabular}

Sumber: diolah dari berbagai sumber

Tabel 6 di atas merupakan berbagai strategi yang dilakukan Sweety untuk mempertahankan pelanggannya agar tetap memilih produk yang ditawarkannya. Berbagai strategi tersebut dilakukan agar merek Sweety lebih dikenal oleh konsumen dan lebih kuat di benak konsumen.

Salah satu strategi yang efektif dilakukan merek Sweety yaitu melalui event dan komunikasi pemasaran diantaranya iklan TV, billboard, print media sedangkan untuk event Sweety banyak menggelar promosi secara langsung melalui kontes foto dan video "Kontes Share dan Kuis Video Sweety Safe and Soft", kontes cerita harapan bunda untuk anaknya dalam program "Sweety Harapan Bunda", penukaran kemasan produk Sweety untuk mendapatkan poin sebanyak-banyaknya dan memenangkan hadih liburan ke Malaysia, Thailand, Vietnam dan Singapura untuk program "Kejutan Poin Sweety" sedangkan hadiah liburan ke Sanrio Puroland Jepang dan hadiah liburan ke Hello Kitty Town Malaysia untuk program "Liburan Keluarga Kompak Sweety". Selain itu acara event yang 
sedang dilaksanakan Sweety yaitu dengan mengadakan lomba bagi anak-anak berusia $<3$ tahun dengan nama "Aksi Bocah Cilik" yang tayang melalui media televisi. Syarat dari keikutsertaan dalam acara ini dimana peserta harus mendaftakran dirinya memalui fanpage Facebook Bunda Cermat milik Sweety.

Sebagai sarana dalam mengkomunikasikan kampanye kegiatan (event) dan produk nya, Sweety memanfaatkan situs jejaring sosial Facebook. Strategi yang gencar dan terus dilakukan oleh Sweety, yaitu peduli akan dunia baru marketing dengan menciptakan berbagai event yang berdampak pada pembentukan suatu komunitas yang mampu menjadi wadah untuk pelanggan, selain itu pemanfaatan dunia digital juga yang gencar dilakukan melalui sosial media sebagai sarana untuk menjalin komunikasi dengan customer-nya.

Cara PT. Softex Indonesia dalam menarik konsumen khususnya kaum ibu yang memiliki bayi dan balita untuk memperkuat ekuitas merek Sweety, maka perlu adanya komunikasi pemasaran yang terintegrasi antara merek, pelanggan dan perusahaan. Salah satu cara yang dilakukan adalah melalui virtual brand community, yaitu grup yang terdiri dari sekelompok individu yang menyukai merek tertentu berkomunikasi menggunakan media elektronik dengan didukung oleh perusahaan pemegang merek. Hal ini diaplikasikan PT. Softex Indonesia pada produk Sweety melalui media sosial Facebook. Komunitas Sweety dalam fanpage Facebook Bunda Cermat memiliki anggota sebanyak 168.458 anggota. Anggota fanpage Bunda Cermat terus bertambah hingga sekarang.

Menurut Sicilia dan Palazon (2008:258)

"Virtual brand community as a group of individuals with common interests in a brand who communicate each other electronically in a platform provided by the company which supports the brand". Artinya Virtual brand community yaitu grup yang terdiri dari sekelompok individu yang menyukai merek tertentu berkomunikasi menggunakan media elektronik dengan didukung oleh perusahaan pemegang merek.

Mortara yang dikutip Petronela dan Iamandi (2010:56) menjelaskan bahwa:

Virtual brand community digambarkan sebagai sekelompok orang ditandai dengan kepentingan bersama dalam merek tertentu dan dengan bantuan teknologi komunikasi interaktif, menciptakan kultur sosial parallel (atau subkultur) yang berjalan dengan adanya mitos, nilai-nilai, ritual, kosa kata tersendiri dan hirarki. Jadi konsep awal komunitas telah membuat makna intinya, hanya dalam bentuk yang mencerminkan perubahan budaya dan komunikasi yang mengalami perubahan dalam decade terakhir ditandai oleh munculnya teknologi computer interaktif atau internet.

Partisipasi yang besar dalam virtual brand community berhubungan dengan pengenalan merek Sweety. Anggota komunitas memerlukan input dari sesama anggota komunitas yang dapat mempengaruhi ekuitas merek dengan menanamkan merek dalam benak dan ingatan konsumen sehingga akan menciptakan citra merek serta mendorong penjualan.

Menurut Stefano Brogi, Armando dan Francesca Di Pillo dalam International Journal of Enginering Business Management 2013 Vol.5 bahwa dinamika online brand community (virtual brand community) dimana partisipasi dari anggota komunitas, konten merek yang dihasilkan, dan persepsi anggota mengenai kualitas merek, memungkinkan mereka untuk berinteraksi dan berbagi pendapat. Hal itu berpengaruh pada ekuitas merek baik mengenai ancaman yang serius maupun kesempatan yang baik untuk merek.

Virtual brand community mempunyai 3 dimensi, diantaranya consciousness of kind, ritual and traditions, serta sense of moral responsibility. Ketiga variabel tersebut dapat diaplikasikan dalam virtual brand community melalui fan page Facebook Bunda Cermat. Para anggota komunitas virtual saling bertukar ide, pengalaman dan informasi lain yang berkaitan dengan topik tertentu yang menarik.

Melihat penjelasan latar belakang yang telah dijelaskan sebelumnya, maka perlu dilakukan penelitian lebih lanjut untuk melihat sejauh mana pengaruh virtual brand community terhadap kinerja ekuitas merek disposable diaper merek Sweety.

Dari uraian latar belakang yang telah saya sampaikan tersebut, maka dapat diajukan sebuah penelitian dengan judul "Analisis Persepsi Virtual Brand Community Terhadap Kinerja Ekuitas Merek Disposable Diaper Merek Sweety" (Survei pada Anggota Fan Page Facebook Bunda Cermat)

Adapun tujuan dari penelitian ini yang hendak dicapai yaitu, untuk memperoleh hasil temuan mengenai:

1. Gambaran virtual brand community pada produk disposable diaper Sweety.

2. Gambaran ekuitas merek produk disposable diaper Sweety. 
3. Pengaruh virtual brand community terhadap ekuitas merek produk disposable diaper Sweety.

\section{KAJIAN PUSTAKA}

Pemasaran merupakan suatu sistem total dari kegiatan bisnis yang dirancang untuk merencanakan, menentukan harga, promosi dan mendistribusikan barang- barang yang dapat memuaskan keinginan dan mencapai pasar sasaran serta tujuan perusahaan. Pemasaran adalah kegiatan pemasar untuk menjalankan bisnis guna memenuhi kebutuhan pasar dengan barang dan atau jasa, menetapkan harga, mendistribusikan, serta mempromosikannya. Seorang pemasar seharusnya memiliki pengetahuan dalam konsep dan prinsip pemasaran agar kegiatan pemasaran dapat tercapai sesuai dengan kebutuhan dan keinginan terutama pihak konsumen yang dituju.

Menurut Kotler dan Keller (2012:8), mendefinisikan "Marketing is a societal process by which individuals and groups obtain what they need and want through creating, offering and freely exchanging products and services of value with others."

Pemasaran adalah suatu proses sosial dimana individu dan kelompok mendapatkan kebutuhan dan keinginan mereka dengan menciptakan, menawarkan dan bertukar barang dan jasa yang bernilai satu sama lain.

Salah satu strategi yang dapat dilakukan oleh perusahaan untuk mencapai tujuannya yaitu dengan menerapkan strategi marketing mix atau bauran pemasaran. Strategi tersebut digunakan untuk mendapatkan keuntungan bagi perusahaan. Bauran pemasaran sebagai salah satu elemen dalam inti pemasaran merupakan cara produsen dalam mengedukasi konsumen terhadap sebuah produk atau jasa. Melalui bauran pemasaran perusahaan dapat mengkomunikasikan apa yang menjadi maksud perusahaan dalam rangka memenuhi kebutuhan dan keinginan konsumen dan mendapatkan keuntungan bagi perusahaan.

Bauran pemasaran ( marketing mix ) menurut Kotler dan Keller (2012:25) yang dikenal dengan "4P" yaitu product, price, place, dan promotion :

1. Product, adalah segala sesuatu yang dapat ditawarkan kepada pasar untuk memuaskan keinginan atau kebutuhan, termasuk didalamnya yaitu product variety, quality, design, features, brand name, packaging, sizes, services, warranties, returns.
2. Price, harga adalah salah satu elemen bauran pemasaran yang menghasilkan pendapatan. Harga bukan hanya angkaangka di label harga. Harga mempunyai banyak bentuk dan melaksanakannya banyak fungsi yang didalamnya termasuk list price, discounts, allowances, payment period, dan credit terms.

3. Place atau distribusi merupakan aktivitas yang dijalankan perusahaan untuk mendistribusikan produknya kepada konsumen sehingga produk dapat diperoleh pada tempat dan waktu yang tepat.terdiri dari Channels, Coverage, Assortments, Locations, Inventory, Transport.

4. Promotion, Promosi adalah sarana dimana perusahaan menginformasikan, membujuk dan mengingatkan konsumen secara langsung maupun tidak langsung tentang produk dan merek yang dijual. Strategi yang dilakukan oleh perusahaan untuk mengkomunikasikan produk adalah dengan menggunakan startegi bauran promosi (promotion mix) yang terdiri dari empat komponen utama yaitu sales promotion, advertising, sales force, public relations, dan direct marketing.

Promosi merupakan salah satu kunci dari keberhasilan suatu organisasi atau perusahaan, walaupun promosi sering dihubungkan dengan penjualan tetapi kenyataannya promosi mempunyai arti yang lebih luas dari penjualan karena penjulaan hanya berhubungan dengan pertukaran hak milik yang dilakukan oleh tenaga penjual, sedangkan promosi adalah setiap aktivitas yang ditujukan untuk menginformasikan, mempengaruhi, dan meningkatkan konsumen untuk tetap menggunakan produk yang dihasilkan perusahaan.

Alat-alat pemasaran biasa dikenal dalam bauran promosi. Kotler dan Amstrong (2012:408) mendefinisikan kelima bagian bauran promosi tersebut sebagai berikut:

1. Advertising (periklanan)

Semua bentuk terbayar dari presentasi non personal dan promosi ide, barang atau jasa melalui sponsor yang jelas.

2. Sales promotion (Promosi penjualan) Berbagai insentif jangka pendek untuk mendorong percobaan atau pembelian produk atau jasa.

3. Personal selling (Penjualan personal) Presentasi pribadi oleh tenaga pemasaran perusahaan yang bertujuan untuk 
membuat penjualan dan membangun hubungan dengan pelanggan.

4. Public relations and publicity (Hubungan masyarakat dan publisitas)

Beragam program yang dirancang untuk mempromosikan atau melindungi citra perusahaan atau produk individunya.

5. Direct marketing (Pemasaran langsung) dan Online marketing

Penggunaan surat, telepon, faksimil, email, atau internet, untuk berkomunikasi secara langsung dengan atau meminta respon atau dialog dari pelanggan dan prospek tertentu.

Salah satu alat komunikasi sering digunakan dalam perusahaan adalah Public relations. Strategi ini banyak digunakan perusahaan karena dinilai cukup efektif dalam menyampaikan dan mengkomunikasikan informasi kepada konsumen atau target pasar.

Public relations merupakan salah satu strategi yang yang dilakukan untuk menjalin hubungan dengan konsumen. Menurut Kotler dan Armstrong (2012:408) "Public relations: Building good relations with the company's various publics by obtaining favorable publicity, building up a good corporate image, and handling or heading off unfavorable rumors, stories, and events".

Berdasarkan penjelasan diatas dapat diartikan bahwa Public relations membangun hubungan baik dengan berbagai perusahaan publik dengan memperoleh pemberitaanyang menguntungkan, membangun citra perusahaan yang baik, dan menangani atau mencegah rumor, cerita dan peristiwa yang tidak menguntungkan.

Menurut Russel, S. Winer (2001: 98) menyebutkan beberapa program costumer relation yaitu costumer service, frequency/ loyality program, customization, dan community building. Community building atau menciptakan sebuah komunitas merupakan salah satu program yang dilakukan perusahaan sebagai sarana berbagi informasi terkait produk dan untuk menciptakan hubungan antara pelanggan, perusahaan dan merek.

Ariela Mortara (2009:3) dalam jurnal The Consumers Community Between The Real and The Virtual Space, mengemukakan community terbagi menjadi 2 jenis, yaitu:

1. Virtual

Perkembangan melalui gagasan manusia menciptakan community melalui penggunaan teknologi. Dengan penggunaan internet, fenomena komunitas virtual menjadi tempat berkumpulnya orang-orang dalam dunia maya. Istilah cyberspace memiliki dimensi sosial yang kuat seperti e-mail, chatting, bermain MOO, posting di forum dan lain-lain. Setiap kegiatan memerlukan suatu interaksi antara pengguna. Kegiatan mulai dari kepentingan bersama dan mendorong pertukaran ide antara individu-individu, mereka menhasilakn komunitas virtual.

2. Real

Hubungan yang terjadi merupakan hubungan manusiawi. Konsumen merupakan mahluk sosial yang memerlukan interaksi langsung dalam kehidupannya. Real community terdapat anggota yang lebih memiliki tanggung jawab moral dibandingkan Virtual community. Karena interaksi yang terjadi langsung terasa secara emosional oleh anggotanya.

Miller (2011:367) berpendapat sebuah komunitas virtual adalah sejenis jaringan sosial yang dilakukan melalui animasi. Artinya, pengguna berinteraksi dengan pengguna lain dalam berbagai busana seperti pada dunia nyata atau seperti yang mereka lakukan di Facebook. Para pengguna diwakili oleh kartun, seperti avatar dan animasi orang kecil yang berjalan di sekitar dunia maya mirip dengan dunia nyata.

Perusahaan menguhubungi konsumen dan memungkinkan interaksi di antara mereka berkembang melalui chatting, forum dan yang lainnya didefinisikan sebagai komunitas virtual. Casalo, Flavian dan Guinaliu (2007:4) mendefinisikan komunitas yang lahir sekitar merek sebagai Virtual Brand Community (VBC).

\section{$\checkmark$ Konsep Virtual Brand Community}

Menurut Sicilia dan Palazon (2008:258) Virtual brand community as a group of individuals with common interests in a brand who communicate each other electronically in a platform provided by the company which supports the brand. Virtual brand community yaitu grup yang terdiri dari sekelompok individu yang menyukai merek tertentu berkomunikasi menggunakan media elektronik dengan didukung oleh perusahaan pemegang merek.

Muniz dan O'Guinn (2001:414) berpendapat bahwa "a specialized, non-geograhically bound community, based on a structured set of social relations among admirers of a brand". Artinya sebuah komunitas yang tidak terikat oleh faktorfaktor geografis, yang didasari oleh seperangkat struktur hubungan sosial diantara para pemuja sebuah merek.

Muniz dan O’Guinn (2001:418-424) menunjukkan sebuah komunitas merek ditandai oleh tiga komponen inti, diantaranya, consciousness of kind (kesadaran akan kebaikan), rituals and traditions (ritual dan tradisi), dan moral of responsibility (tanggung jawab moral). 
1. Consciousness of kind (Kesadaran akan kebaikan)

Consciousness of a kind is the intrinsic connections that members feel toward one another and the collective sense of difference from others not in the community. It is a shared knowing of belonging. Artinya anggota komunitas melalui keterkaitannya satu sama lain menciptakan kesadaran sejenis sebagai satu kesatuan yang secara kolektif memunculkan perasaan berbeda dari orang lain di luar komunitas, sekaligus keterkaitan serta kebersamaan pada komunitas, sesama anggota dan merek.

2. Rituals and traditions (Ritual dan tradisi)

Shared rituals and traditions perpetuate the community's shared history, culture and consciousness and includes activity of sharing brand stories. By sharing the comments of other community members, any one member feels more secure in his or her understanding thet are many like-minded others "out there". Artinya anggota komunitas biasanya berbagi aktivitas, ritual dan kebiasaan yang sama yang berangkat dari latar belakang atau pengalaman, nilai-nilai dan kesadaran yang sama terhadap merek. Saling berbagi pengalaman dan pendapat dengan sesama anggota komunitas menciptakan perasaan nyaman beraa di tengah-tengah orang yang mempunyai pemahaman dan pemikiran sama yang terkumpul dala satu komunitas.

3. Sense of moral responsibility (Tanggung jawab moral)

Moral responsibility, which is felt as a sense of duty or obligation to the community as a whole, to its members and to the brand. It produces collective action in times of threat to the community and the brand. Artinya anggota komunitas memiliki tanggung jawab moral, baik terhadap komunitasnya, anggotanya, maupun merek yang diusung bersama, yang terwujud dengan adanya aksi kolektif yang muncul pada saat ada ancaman, baik terhadap komunitas, anggota komunitas dan merek.

\section{$\checkmark$ Konsep Ekuitas Merek}

Menurut Kotler dan Keller (2012:243) Brand equity is the added value endowed on products and services. It may be reflected in the way consumers think, feel, and act with respect to the brand, as well as in the prices, market share and profitability the brand commands. Ekuitas merek adalah nilai tambah yang diberikan pada produk dan jasa. Ekuitas merek dapat tercermin dalam cara konsumen berfikir, merasa dan bertindak dalam hubungannya dengan merek, dan juga harga, pangsa pasar dan profitabilitas yang diberikan merek bagi perusahaan.

Menurut Kotler dan Keller (2012:263), tiga kunci pokok penciptaan ekuitas merek yaitu, pertama, ekuitas merek timbula kibat perbedaan respon konsumen. Kedua, pengetahuan konsumen mengenai merek (brand knowledge). Ketiga, respon diferensial dari konsumen. Karena itu, tantangan bagi pemasar dalam membangun merek yang kuat adalah memastikan bahwa pelanggan memiliki jenis pengalaman yang tepat dengan produk, jasa dan program pemasaran merek untuk menciptakan pengetahuan merek yang diinginkan.

Model ekuitas merek ini terdapat empat langkah proses dalam membangun merek, yakni:

1. Menyusun identitas merek yang tepat (who are you?)

2. Menciptakan makna merek yang sesuai (what are you?)

3. Menstimulasi respon merek yang diharapkan (what about you?)

4. Menjalin relasi merek yang tepat dengan pelanggan (what about you and me?)

Proses implementasi keempat tahap diatas membutuhkan enam building block utama yakni seperti dalam Gambar 4 berikut.

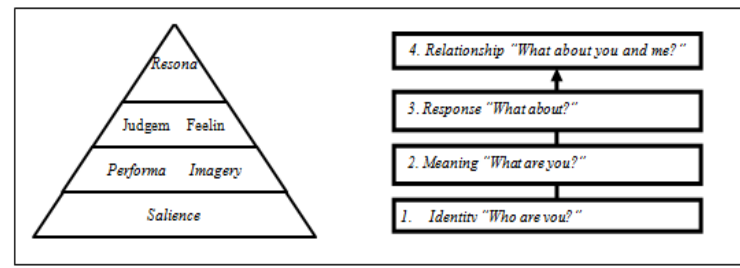

Sumber: Keller (2008:260)

GAMBAR 4

CUSTOMER-BASED BRAND EQUITY MODEL

Proses implementasi model ekuitas merek menurut Gambar 4 dipaparkan oleh Kotler dan Keller (2012:248-249) dan Keller (2008:259261) dalam penjelasan sebagai berikut.

\section{Brand salience}

Brand salience is how often and how easily customers think of the brand under various purchase or consumtion situations. Dapat diartikan bahwa seberapa sering dan seberapa mudah pelanggan memikirkan merek dibawah berbagai pembelian atau konsumsi pada berbagai situasi. Brand salience berkenaan dengan aspek- 
aspek awareness sebuah merek, seperti sebarapa sering dan mudah sebuah merek diingat dan dikenali dalam berbagai situasi. Faktor ini menyangkut seberapa baik elemen merek menjalankan fungsinya sebagai pengidentifikasi produk. Brand awareness bukan hanya sekedar menyangkut apakah konsumen mengetahui nema merek, namun berkaitan pula dengan mengaitkan merek (nama, logo, symbol dan seterusnya) dengan asosiasi-asosiasi tertentu dalam memori konsumen yang bersangkutan. (Keller,2008:259).

\section{Brand performance}

Brand performance is how well the product or service meets customers functional needs, artinya bahwa kinerja merek adalah seberapa baik produk atau jasa memenuhi kebutuhan fungsional pelanggan. Brand performance berkenaan dengan kemampuan produk atau jasa, yaitu memenuhi kebutuhan fungsional konsumen. Secara garis besar ada lima atribut dan manfaat pokok yang mendasari kinerja merek yakni sebagai berikut.

a. Unsur primer dan suplemen,

b. Realibilitas, durabilitas dan serviceability produk,

c. Efektivitas, efisiensi dan empati layanan,

d. Model dan desain,

e. Harga.

Pada hakikatnya kinerja merek mencerminkan intrinsic properties merek dalam hal karakteristik interen sebuah produk atau jasa.

\section{Brand imagery}

Brand imagery describes the extrinsic properties of the product or service, including the ways in which the brand attempts to meet customers psychological or social needs. Dalam artian citra merek menggambarkan sidat ekstrinsik dari produk atau jasa, termasuk cara di mana merek berusaha untuk memenuhi kebutuhan pelanggan psikologis atau sosial. Brand imagery dapat terbentuk secara langsung (melalui pengalaman konsumen dan kontaknya dengan produk, merek, pasar sasaran atau situasi pemakaian) dan tidak langsung (melaui iklan dan komunikasi). Terdapat empat kategori utama brand imagery, yaitu:

a. Profil pemakai, baik berdasarkan faktor demografis deskriptif (usia, gender, rasa tau pendapatan) maupun psikologis abstrak (sikap terhadap hidup, karir, kepemilikan, isu sosial, maupun institusi politik).

b. Situasi pembelian (berdasarkan tipe saluran distribusi, took spesifik, kemudahan pembelian dan sejenisnya) dan situasi pemakaian (kapan dan dimana merek digunakan).

c. Kepribadian, gaya hidup dan nilai-nilai.

d. Sejarah, warisan budaya (heritage) dan pengalaman.

4. Brand judgement

Brand judgement focus on consumers own personal opinions and evaluations. Penilaian sebuah merek berfokus pada pendapat dan evaluasi personal konsumen terhadapa merek berdasarkan kinerja merek dan asosiasi citra yang dipersepsikannya. Aspek brand judgement meliputi:

a. Brand quality, persepsi konsumen terhadap nilai dan kepuasan yang dirasakannya.

b. Brand credibility, yakni seberapa jauh merek dinilai kredibel dalam hal expertice (kompeten, inovatif, pemimpin pasar), trustworthiness (bisa diandalkan dan selalu mengutamakan kepentingan konsumen), dan like ability (menarik, menyenangkan dan layak untuk dipilih dan digunakan).

c. Brand consideration, yakni sejauh mana konsumen menilai merek yang bersangkutan unik dan lebih baik dibandingkan merek-merek lain.

5. Brand feelings

Brand feelings are customers emotional responses and reactions with respect to the brand. Brand feelings merupakan respon dan reaksi emosional konsumen terhadap merek. Reaksi semacam ini bisa berupa perasaan kehangatan, menyenangkan, kenyamanan, kegembiraan, rasa aman, rasa dekat dengan lingkungan sosial dan menghargai diri sendiri.

\section{Brand resonance}

Brand resonance describe the relationship customers have with the brand and the axtent to which they feel they are "in sync" with it. Menggambarkan pelanggan yang memiliki hubungan dengan merek dan apa yang dirasakan oleh para konsumen. Brand resonance mengacu pada karakteristik relasi yang dirasakan konsumen terhadapa merek spesifik. Resonansi tercermin pada intensitas atau kekuatan ikatan psikologis antara pelanggan dan merek, serta tingkat aktivitas yang ditimbulkan loyalitas tersebut.

\section{$\checkmark$ Analisis Persepsi Virtual Brand Community Terhadap Kinerja Ekuitas Merek}

Seperti yang telah diuraikan sebelumnya, bahwa di dalam dunia bisnis persaingan tidak dapat dihindarkan sehingga perusahaan harus menerapkan managemen pemasaran secara maksimal, khususnya konsep pemasaran agar 
dapat memenangkan persaingan. Secara umum usaha untuk meningkatkan ekuitas merek suatu produk dilakukan melalui manajemen merek yaitu adayna wadah komunitas secara lansung antara pelanggan dan pemegang merek.

Menurut Sicilia dan Palazon (2008:258) virtual brand community yaitu grup yang terdiri dari sekelompok individu yang menyukai merek tertentu berkomunikasi menggunakan media elektronik dengan didukung oleh perusahaan pemegang merek.

Menurut Stefano Brogi, Armando dan Francesca Di Pillo dalam International Journal of Eginering Business Management 2013 Vol.5 bahwa dinamika online brand community (virtual brand community) dimana partisipasi dari anggota komunitas, konten merek yang dihasilkan, dan persepsi anggota mengenai kualitas merek, memungkinkan mereka untuk berinteraksi dan berbagi pendapat. Hal itu berpengaruh pada ekuitas merek baik mengenai ancaman yang serius maupun kesempatan yang baik untuk merek

Pada tahun 2014 As'ad, H. AbuRumman, melakukan penelitian terhadap The Impact of Social Media Marketing on Brand Equity: An Empirical Study on Mobile Service Providers in Jordan Berdasarkan hasil studi menunjukkan hubungan yang kuat antara pemasaran media sosial dan ekuitas merek, pemasaran media sosial adalah alat yang sangat penting bagi perusahaan khususnya penyedia layanan mobile.

Selain itu Marcelo dan Paolo (2010) melakukan penelitian terhadap The influence of belonging to virtual brand communities on consumers' affective commitment, satisfaction and word-of-mouth advertising The ZARA case dengan hasil penelitian Perasaan saling memiliki dalam komunitas virtual dapat meningkatkan kepuasan konsumen, komitmen, word of mouth yang efektif terhadap merek sekitar pada komunitas yang dikembangkan. Partisipatif aktif memiliki pengaruh tingkat kepuasan dan komitmen afektif lebih positif daripada rasa anggota komunitas yang pasif dan nonpartisipatif.

Berdasarkan pernyataan para ahli dan hasil penelitian terdahulu, dapat dikatakan bahwa salah satu pengaruh persepsi Virtual Brand Community dapat meningkatkan kinerja ekuitas merek.

Berdasarkan pendapat tersebut, maka penulis mengemukakan paradigma penelitian pada Gambar 5 berikut.

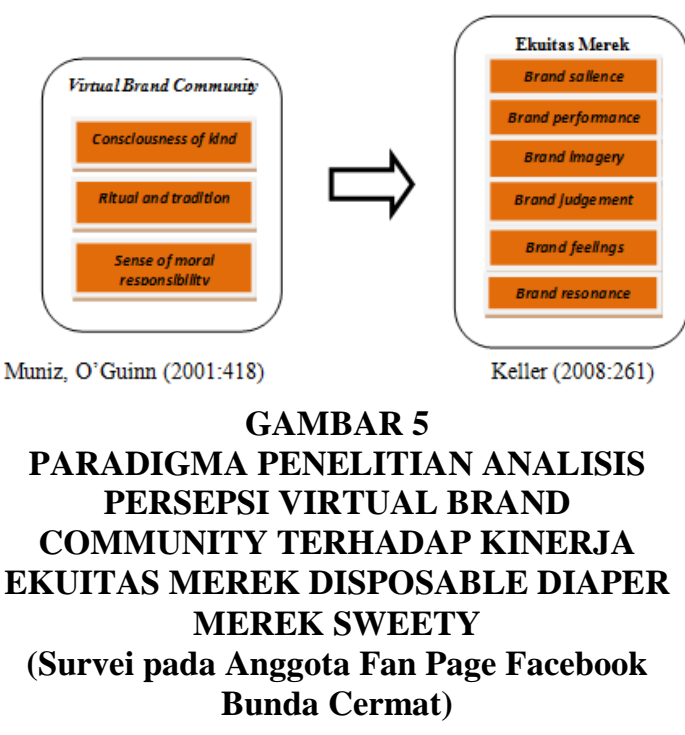

\section{METODE PENELITIAN}

Objek penelitian dalam penelitian ini adalah virtual brand community sebagai variabel bebas (Independent Variable) yang pertama terdiri dari yang terdiri dari consciousness of kind, ritual and tradition, dan sense of moral responsibility sedangkan variabel terikat (dependent variable) adalah ekuitas merek.

Berdasarkan jenis variabel yang diteliti maka penelitian yang dilakukan adalah bersifat deskriptif dan verifikatif. Penelitian deskriptif bertujuan untuk memperoleh gambaran, sesuai dengan rumusan masalah maka dapat diperoleh deskripsi mengenai, gambaran persepsi virtual brand community dan gambaran ekuitas merek disposable diaper merek Sweety. Tujuan verifikatif yaitu untuk memperoleh besarnya pengaruh persepsi virtual brand community dan gambaran ekuitas merek disposable diaper merek Sweety

Berdasarkan uraian penelitian deskriptif dan verifikatif yang dilaksanakan melalui pengumpulan data di lapangan, maka metode yang digunakan dalam penelitian ini adalah metode survei atau explanatory survey yang bertujuan untuk mengetahui hubungan antar variabel dengan cara pengujian hipotesis.

Objek yang menjadi responden dalam penelitian ini adalah anggota fan page Facebook Bunda Cermat. Penelitian ini dilakukan untuk mengetahui bagaimana persepsi responden terhadap virtual brand community pengaruhnya terhadap koinerja ekuitas merek disposable diaper merek Sweety. 
Penelitian ini dilakukan pada kurun waktu kurang dari satu tahun, maka metode penelitian yang lebih tepat untuk digunakan adalah cross sectional method. Menurut Umar Husein (2008:45) menjelaskan bahwa, "Metode cross sectional yaitu metode penelitian dengan cara mempelajari objek dalam satu kurun waktu tertentu atau tidak berkesinambungan dalam jangka waktu panjang". Suatu penelitian yang datanya dikumpulkan sekaligus, merupakan hasil sekali bidik (one snapshot) pada satu saat tertentu disebut penelitian cross sectional (Asep Hermawan 2009:89)

Populasi dalam penelitian ini adalah anggota $f n$ page Facebook Bunda Cermat. Berdasarkan teknik penarikan sampel secara simple random sampling dan hasil perhitungan rumus slovin didapatkan bahwa sampel yang digunakan berjumlah 99,94 responden, dibulatkan menjadi 100 responden.

\section{HASIL PENELITIAN DAN PEMBAHASAN 1. PEMBAHASAN DESKRIPTIF \\ $\checkmark$ Virtual Brand Community}

Virtual Brand Community terdiri dari 3 dimensi, yaitu consciousness of kind, ritual and tradition, dan sense of moral responsibility.

Dari ketiga dimensi virtual brand community dimensi consciousness of kind memperoleh total nilai tertinggi yaitu sebesar 4037 (82,4\%). Hal tersebut mengindikasikan bahwa dimensi consciousness of kind yang diukur dengan keaktifan anggota dalam berkomunikasi, memberi komentar, tanggapan, keikutsertaan dalam program, dari hasil tersebut termasuk dalam kategori tinggi.. Sedangkan untuk dimensi yang memiliki total nilai terendah dalam virtual brand community ialah dimensi ritual and tradition dengan skor $2644(75,5 \%)$.

\section{$\checkmark$ Ekuitas Merek}

Ekuitas merek terdiri dari 6 indikator, yaitu brand salience, brand performance, brand imagery, brand judgemant, brand feelings dan brand resonance.

Berdasarkan hasil rekapitulasi mengenai tanggapan responden mengenai variabel ekuitas merek, dimensi Brand Judgemant memiliki nilai atau jumlah skor tertinggi sebesar 2100 (79,1\%), artinya dimensi brand judgemant yang diukur dengan inovasi produk keunikan produk dan keandalan produk terhadap pemenuhan kabutuhan konsumen, dari hasil tersebut termasuk dalam kategori tinggi Nilai atau jumlah skor terendah pada variabel ekuitas merek diperoleh oleh dimensi brand salience dan brand performance dengan perolehan skor $2138(76,4 \%)$.

\section{PEMBAHASAN VERIFIKATIF}

$\checkmark$ Analisis Persepsi Virtual Brand Community Terhadap Kinerja Ekuitas Merek Disposable Diaper Merek Sweety

Untuk menguji pengaruh virtual brand community, maka dilakukan perhitungan regresi linier sederhana dengan aplikasi software SPSS (Statistical Product for Service Solution) 20.0 dan dibantu software microsoft excel.

Diperoleh model summary dengan menggunakan aplikasi software SPSS (Statistical Product for Service Solution) 20.0 maka dapat diperoleh hubungan antara virtual brand community terhadap kinerja ekuitas merek secara rinci berikut:

TABEL 7

MODEL SUMMARY

\begin{tabular}{|c|r|r|r|}
\hline Model & $\mathrm{R}$ & R Square & $\begin{array}{c}\text { Adjusted R } \\
\text { Square }\end{array}$ \\
\hline 1 & $.902^{\mathrm{a}}$ & .813 & .811 \\
\hline
\end{tabular}

SumberL: Hasil Pengolahan

Berdasarkan Tabel 7 model summary output SPSS 20.0, dapat diketahui bahwa korelasi atau hubungan antara virtual brand community dengan ekuitas merek memperoleh hasil sebesar 0,902 (positif). Sesuai dengan pedoman untuk memberikan interpretasi terhadap koefisien korelasi (Sugiyono, 2011:250), maka korelasi antara virtual brand community terhadap ekuitas merek termasuk kategori sangat kuat $(0,80-$ 1,000) dengan Standar Error Of Estimate (SEE) sebesar 6.961.

Kemudian pada Tabel 7 diperoleh angka $R$ Square untuk virtual brand community ialah 0,813 artinya ekuitas merek dipengaruhi oleh virtual brand community sebesar $81,3 \%$ sedangkan $18,7 \%$ nya dipengaruhi oleh faktor lain.

Dari hasil output koefisien regresi linear sederhana, diperoleh persamaan regresi linear sederhana antara virtual brand community terhadap ekuitas merek, yaitu sebagai berikut:$$
\mathbf{Y}=\mathbf{a}+\mathbf{b X}
$$$$
\text { Ekuitas Merek = 16,449 + 1,093 X Virtual }
$$$$
\text { Brand Community }
$$

Berdasarkan persamaan regresi di atas, besar perubahan ekuits merek (Y) yang terjadi mengikuti perubahan virtual brand community (X) yaitu sebesar 3,345. Artinya apabila jika tidak 
ada kinerja viral marketing $(\mathrm{X}=0)$ maka brand equity sebesar 16,449 satu satuan nilai. Koefesien regresi 1,093 satuan nilai dimana setiap terjadi peningkatan virtual brand community sebesar satu satuan nilai, akan meningkatkan ekuitas merek sebesar 1,093 satuan nilai dan sebaliknya jika terjadi penururnan virtual brand community sebesar satu satuan nilai akan menurunkan ekuitas merek sebesar 1,093 satuan nilai. Untuk

mengetahui besarnya pengaruh variabel $\mathrm{X}$ terhadap Y, maka digunakan rumus koefisien determinasi sebagai berikut:

Keterangan :

$$
\mathrm{KD}=\mathrm{r}^{2} \times 100 \%
$$

$\mathrm{r}^{2}=$ koefisien korelasi

Berikut adalah hasil perhitungan koefisien determinasi dari $\mathrm{X}$ dan $\mathrm{Y}$ :

$$
\begin{array}{rl}
\mathrm{KD}=\mathrm{r} 2 \times 1 & 100 \% \\
& =(902) 2 \times 100 \% \\
& =81,3 \%
\end{array}
$$

Koefisien determinasi untuk virtual brand community (X) terhadap ekuitas merek (Y) adalah $81,3 \%$. Dengan kata lain kinerja karyawan dipengaruhi $81,3 \%$ oleh virtual brand community sedangkan $18,7 \%$ dipengaruhi oleh faktor - faktor lainnya.

\section{$\checkmark \quad$ Implikasi Hasil Penelitian Pengaruh Sistem Penghargaan Dan Motivasi Kerja Terhadap Kinerja Karyawan Terhadap Pengembangan Pendidikan Manajemen Bisnis}

Pendidikan adalah suatu proses yang dilakukan secara sadar atau disengaja guna untuk menambah pengetahuan, wawasan serta pengalaman untuk menentukan tujuan hidup sehingga bisa memiliki pandangan yang luas untuk kearah depan lebih baik dan dengan pendidikan itu sendiri dapat menciptakan orangorang berkualitas.

Pendidikan merupakan komponen yang memiliki peran yang strategis bagi bangsa Indonesia dalam mewujudkan tujuan yang telah dirumuskan. Salah satu tujuan bangsa Indonesia yang tertuang dalam Pembukaan UUD 1945 pada alinea ke empat adalah "mencerdaskan kehidupan bangsa". Untuk mewujudkan hal tersebut dibutuhkan usaha yang terencana dan terprogram dengan jelas dalam agenda pemerintahan yang berupa penyelenggaraan pendidikan.

Pekembangan dunia pendidikan mengalami perubahan yang terus-menerus yang disesuai kan dengan perkembangan zaman. Hal ini dimaksudkan untuk menciptakan suatu tatanan kehidupan yang lebih baik untuk masa depan, sebagaimana tercantum dalam undang-undang No. 20 tahun 2003 tentang sistem pendidikan nasional yang menjelaskan bahwa :

Pendidikan adalah usaha sadar dan terencana untuk mewujudkan suasana belajar dan proses pembelajaran agar peserta didik secara aktif mengembangkan potensi dirinya untuk memiliki kekuatan spiritual keagamaan, pengendalian diri, kepribadian, kecerdasan, akhlak mulia serta keterampilan yang diperlukan dirinya, masyarakat, bangsa dan negara.

Sesuai dengan undang-undang tersebut pendidikan merupakan usaha sadar dan terencana yang dimaksudkan untuk menigkatkan kemampuan manusia dalam mengembangkan kemampuan yang dimilikinya. Pendidikan yang diterapkan tidak hanya bersifat formal tetapi berupa sarana aktualisasi diri yang bersifat menyeluruh dalam rangka meningkatkan taraf hidup manusia.

Pendidikan Manajemen Bisnis merupakan jenjang pendidikan lanjutan strata satu, yang dikembangkan oleh Universitas Pendidikan Indonesia, yang secara khusus didirikan untuk mendukung pengembangan pendidikan, terutama dalam bidang kajian pendidikan tata niaga atau manajemen bisnis. Dalam pengembangan Pendidikan Manajemen Bisnis senantiasa memperhatikan perkembangan ilmu manajemen khususnya manajemen pemasaran yang menjadi bagian dari Pendidikan Manajemen Bisnis. Maka dengan mengetahui hasil dari penelitian ini diharapkan dapat memberikan sumbangan ilmu pengetahuan pemasaran khususnya pada kajian virtual brand community dan ekuitas merek.

Hasil penelitian ini implikasinya terhadap Pendidikan Manajemen Bisnis diharapkan adanya penambahan pengetahuan yang dapat dijadikan pembekalan mengenai pemasaran khususnya mengenai virtual brand community dan ekuitas merek yang saling mempengaruhi satu sama lain. Pendidikan Manajemen Bisnis merupakan salah satu program studi di Universitas Pendidikan Indonesia yang senantiasa mengikuti serta turut mendukung dalam upaya pengembangan ilmu pengetahuan khususnya pada ilmu pengetahuan pada bidang pendidikan manajemen bisnis.

Proses pembentukan kepribadian mahasiswa menjadi lebih baik merupakan tugas pokok dalam suatu lembaga pendidikan 
khususnya pada Program Studi Pendidikan Manajemen Bisnis, peningkatan dan pembentukan mahasiswa menjadi lebih baik dapat dijadikan bekal kelak dalam memasuki lapangan usaha maupun dunia kerja.

Berdasarkan hasil penelitian, persaingan dalam dunia usaha memaksa para pelaku usahanya melakukan berbagai cara yang inovatif dan meningkatkan kualitas tidak hanya produk, tetapi cara memasarkannya. Melalui pengaplikasian dari dimensi-dimensi baik virtual brand community maupun ekuitas merek diharapkan mampu meningkatkan pengetahuan masyarakat sekaligus membawa nama baik Pendidikan Manajemen Bisnis bagi masyarakat.

Ekuitas merek merupakan salah satu indikator sebagai penegas bahwa suatu perusahaan memiliki posisi yang kuat di pasaran. Adapun untuk memperkuat suatu merek makan dilakukan berbagai strategi komunikasi untuk menyampaikan dan mengkomunkasikan merek tersebut ke pasar. Stategi tersebut dimaksudkan tidak hanya untuk mengkomunikasikan suatu merek tetapi juga dapat dijadikan sebagai sarana untuk mengingatkan sekaligus mengajak konsumen dalam menggunakan produk yang dipasarkan.

Terjadinya perubahan media komunikasi tradisional ke media komunikasi virtual menjadikan virtual brand community merupakan salah satu program komunitas yang patut untuk dilakukan. Hal ini berkaitan dengan maraknya penggunaan media jejaing sosial secara luas yang dilakukan konsumen sebagai alat komunikasi yang interaktif yang dihubungkan dengan koneksi internet.

Pembentukan suatu komunitas melalui program virtual brand community tidak hanya dilakukan oleh perusahaan saja, strategi tersebut turut dilakukan oleh sejumlah lembaga-lembaga pendidikan untuk menarik minat para siswa untuk masuk kedalam lembaga pendidikan tersebut. Salah satu lembaga yang turut melakukan program virtual brand community yakni Universitas Pendidikan Indonesia (UPI) sebagai salah satu Perguruan Tinggi Negeri (PTS) di Kota Bandung menggunakan media internet melalui situs internet maupun jejaring sosial dalam meunjang promosi.

Situs internet (website) dan fanpage jejaring sosial seperti Twitter dan Facebook yang digunakan UPI memberikan informasi seputar kegiatan akademis maupun non-akademis.
Adapun informasi yang disajikan berupa berita, informasi seputar kampus, sarana dan prasarana, pengumuman kegiatan belajar, jadwal perkuliahan, acara kemahasiswaan dan sarana interaksi komunikasi.

Penggunaan media internet tersebut tidak lain dilakukan UPI untuk mempermudah masyarakat dalam mengakses informasi sebagai wujud dedikasi UPI dalam memahami kebutuhan masyarakat dan digitalisasi global. Selain itu, penyediaan website tersebut ditujukan untuk meningkatkan kepercayaan masyarakat terhadap UPI sebagai lembaga penyelenggara pendidikan yang intergitas yang tinggi.

\section{KESIMPULAN DAN REKOMENDASI}

$\checkmark$ Kesimpulan

Berdasarkan hasil penelitian yang telah dilaksanakan dengan berdasarkan kepada uraian teori-teori dan pengujian analisis korelasi dan regresi linier sederhana mengenai pengaruh virtual brand community terhadap ekuitas merek disposable diaper merek Sweety dapat disimpulkan sebagai berikut:

1. Gambaran mengenai penerapan virtual brand community yang dilaksanakan oleh Sweety, termasuk pada kategori tinggi dengan perolehan skor sebesar 78,8\%. Hal tersebut merupakan penilaian responden yang diukur berdasarkan dimensi-dimensi yang dimiliki virtual brand community yang terdiri dari consciousness of kind, ritual and tradition dan sense of moral responsibility. Virtual brand community telah dilaksanakan dengan baik oleh Sweety terutama pada dimensi consciousness of kind dalam keaktifan anggota membuka halaman fan page Facebook Bunda Cermat dan keaktifan berkomunikasi antara anggota. Adapun penilaian paling rendah ditunjukan oleh dimensi ritual and tradition .

2. Gambaran dari ekuitas merek yang diukur berdasarkan dimensi brand salience, brand performance, brand imagery, brand judgement, brand feelings dan brand resonance, termasuk pada kategori tinggi dengan perolehan skor sebesar 72,2\%. Berdasarkan penilaian responden, dimensi yang memiliki penilaian paling tinggi ditunjukan oleh dimensi brand judgement, dimana citra dan kinerja merek Sweety dinilai baik Sedangkan untuk dimensi dengan penilaian paling rendah ditunjukan oleh dimensi brand performance. Hal ini 
menujukan bahwa kualitas Sweety kurang memberikan kepuasan karena tidak sesuai dengan harga.

3. Virtual brand community memiliki pengaruh yang positif terhadap ekuitas merek diaper Sweety dengan perolehan nilai korelasi yang sangat tinggi atau sangat kuat yaitu sebesar 0,902. Dengan kata lain semakin tinggi intensitas virtual brand community yang dilakukan, maka akan semakin tinggi pula ekuitas merek diaper Sweety.

\section{$\checkmark$ Rekomendasi}

Berdasarkan hasil penelitian, maka penulis merekomendasikan beberapa hal mengenai virtual brand community terhadap ekuitas merek sebagai berikut:

1. Penerapan virtual brand community yang telah dilakukan pada diaper Sweety secara menyeluruh memiliki pengaruh dan termasuk pada kategori sangat baik pengaruhnya terhadap ekuitas merek, namun ada beberapa hal yang perlu diperbaiki terkait dengan ritual and tradition dari pesan yang disampaikan sehingga diaper Sweety memiliki suatu komunitas yang diantara anggotanya terjalin hubungan saling memberi saran dalam permasalahan seputar penggunaan diaper pada bayi. Admin sebagai pemegang merek harus lebih aktif untuk mengajak anggota ingin berkomentar dan saling berbagi cerita seputar permalsalahan pada diaper. Sehingga dengan adanya komunikasi antar anggota dapat menimbulkan efek positif bagi merek Sweety.

2. Beberapa upaya dilaksanakan Sweetya dalam rangka membangun ekuitas merek yang kuat mampu memberikan respon yang baik di mata responden. Namun ada bebrapa hal yang perlu diperhatikan mengenai brand salience dan brand performance supaya konsumen tidak berpindah pada merek lain. Untuk itu Sweety harus mampu memberikan kualitas diaper yang baik karena harga yang dipasarkan relative sama dengan diaper yang lain dimana kulaitas dari diaper yang lain dinilai lebih baik. Aspek lainnya yang perlu ditingkatkan yakni intensitas interaksi penyampaian informasi yang berujung pada terbentuknya suatu komunitas virtual melalui media-media yang sedang banyak digunakan masyarakat seperti jejaring sosial Facebook, Twitter dan jejaring sosial lainnya. Hal tersebut dilakukan guna menjaga hubungan baik antara perusahaan dengan kosumen sehingga terciptanya suatu loyalitas yang kuat.

3. Hasil penelitian yang telah dilakukan memberikan suatu kebenaran bahwasannya virtual brand community yang dilakukan oleh Sweety mampu meningkatkan ekuitas merek diaper Sweety. Dengan demikian penulis merekomendasikan supaya perusahaan tetap menjaga, mempertahankan, megawasi dan menigkatkan kembali ekuitas merek melalui pelaksanaan program virtual brand community dengan berisikan posting-posting yang menarik, mendidik serta menghibur konsumen. Selain itu penelitian ini juga diharapakan dapat dijadikan sebagai dasar dalam melakukan penelitian mengenai virtual brand community dengan indikator serta objek yang beberda.

4. Virtual brand community yang dilakukan perusahaan di masa mendatang hendaknya dilakukan dengan cara yang lebih baru dan efisien dalam memberikan informasi seputar produk yang dipasarkan. Dibentuknya suatu komuitas sebagai ajang sharing yang dapat memberikan solusi atau tips-tips seputar produk, dapat meyakinkan dan menambah pengetahuan konsumen sehingga dapat menciptakan suatu buzz yang tidak hanya berguna tetapi juga dapat menjadi rekomendasi bagi konsumen lainnya.

\section{DAFTAR PUSTAKA}

As'ad, H. Abu-Rumman. 2014. The Impact of Social Media marketing on Brand Equity: An Empirical Stuqy on Mobile Service Providers in Jordan. Journal Society of Interdiciplinary Business Research Vol. 3 No. 1 ISSN: 23041013;2304-1269

Brogi, Stefano., Armando and Di Pillo, Fransesca. 2013. The Effect of Online Brand Communities on Brand Equity in The Luxury Fashion Industry. International Journal of Eginering Business Management Special Issue on Inovations in fashion Industry Vol.5 DOI: 10.5772/56854 pp.4-12

Casalo, L.V, Flavian, C. Guinaliu, M. 2007. Antecedents Effects of Participation in Virtual Brand Communities. IADIS International Conference on Web Based Communities journal. pp 3-10 
Husein, Umar. 2008. Metode Riset Bisnis. Bandung: Alfabeta.

Kotler, Philip dan Gary Amstrong. 2012. Manajemen Pemasaran. Jakarta: PT INDEKS Kelompok Gramedia.

Kotler, Philip dan Kevin Lane Keller. 2009. Manajemen Pemasaran. Edisi 13 jilid 2. Jakarta: Erlangga.

Marketing Management. Fourtheenth Edition. Pearson Education, Inc.

Marcelo, R., dan Paolo C. 2010. The influence of belonging to virtual brand communities on consumers' affective commitment, satisfaction and word-of-mouth advertising The ZARA case. Online Information Review Vol. 35 No. 4, pp. 517-542. DOI: $10.1108 / 14684521111161918$.

Michael, Miller. 2011. The Ultimate Web Marketing Guide. Pearson Education, Inc.

Mortara, Ariela. (2009). The Consumers' Community Between The Real and The. Virtual Space, Journal of marketing.

Muniz, A and O'Guinn, T.C. 2001. Brand communities. Journal of Consumer Research, Vol. 27 No. 4, pp. 412-32. 0093-5301/2001/2704-0002\$03.00

Petronela, P., dan Iamandi, C. D. 2010. Thesis A case of Strategic Online Communication in Postmodernism. Using Facebook to Create Virtual Brand Communities. AARHUS SCHOOL OF BUSINESS

Sicilia, M., dan Palazon, M. 2008. Brand Communities on the internet, A case study of Coca-Cola's Spanish virtual brand community. Corporate Communications: An International Journal Vol. 13 No. 3. pp. 255-270. DOI 10.1108/13563280810893643 